\title{
EDITORIAL
}

\section{Should Healthcare Facilities Mandate COVID-19 Vaccination of its Employees?}

There has been a lot of controversy recently surrounding the decision by a major healthcare facility in Houston, Texas mandating that all of its 26,000 employees must be vaccinated against SARS-CoV-2 virus by June 07,2021 , or else face suspension and/or dismissal (1). It was the first major hospital system in the U.S., to take this rather bold decision particularly since the COVID-19 vaccine is currently being administered under an Emergency Use Authorization (EUA) issued on December 11, 2020, by the U.S. Food and Drug Administration (2). Houston Methodist Hospital has taken this decision in the best interest of patient safety arguing that it is a complex, team-oriented responsibility requiring active effort of every member of the healthcare team. Needless to say, patient safety is the most vital and tacit contract between the healthcare providers and the patients and it is the core element of the principle of nonmalfeasance - do no harm which dictates the practice of medicine and is the legal and ethical framework to which all healthcare workers ascribe.

What has been the outcome of this decision and what are its ethical and legal manifestations? Since Houston Methodist announced their decision to mandate COVID-19 vaccination for all of its employees, over 1,200 employees have voluntarily left the organization and another 117 have filed a lawsuit against the healthcare facility in the Texas High Court challenging this directive (3). In this lawsuit, the employees have argued that their employer's compulsory immunization requirement violated the Nuremberg Code, a set of standards designed after World War Two to prevent experimentation on human subjects without their consent (4). They have also declared that the hospital presented them with the choice of either getting a vaccine or losing their job, which violated state law, and demanded that the court prevent Houston Methodist from firing unvaccinated staffers.
It has been argued that since the COVID-19 vaccines are being administered under an EUA, therefore their use must be considered experimental. It is important to emphasize that the process to issue EUA for COVID-19 vaccines involved a very rigorous scientific review by a panel of independent experts both at the level of the FDA and the Centers for Disease Control \& Prevention. In this process, data from randomized placebocontrolled studies involving over 100,000 adults using various COVID-19 vaccines was meticulously evaluated for both safety and efficacy $(5,6)$. Subsequently, similar randomized placebocontrolled studies in pregnant women and adolescents also yielded analogous outcomes and confirmed the safety and the efficacy of these vaccines $(7,8)$. The safety and efficacy of the COVID-19 vaccines has also been confirmed by mass vaccinations in the U.S. As of June 7, 2021, over 301 million doses of vaccines have been administered in the U.S. with minimal adverse events (9). In Texas alone, as of June 07, 2021, over 22 million doses of COVID-19 vaccines have been administered with similar safety outcomes (10). It is noteworthy that safety and efficacy of two of the three approved COVID-19 vaccines in the U.S., has also prompted both Pfizer-BioNTech and Moderna to apply for full FDA approval of their respective vaccines $(11,12)$.

The issue of legality of mandating vaccination in the face of a public health crisis was addressed by the U.S. Supreme Court during the smallpox epidemic in the city of Cambridge, Massachusetts in 1905 (13). In the case Jacobson v. Massachusetts, the U.S. Supreme Court upheld the right of the city of Cambridge, Massachusetts, to mandate vaccination against smallpox. Rejecting the contention that mandatory vaccination violated an individual's rights to due process and equal protection as guaranteed by the 14th Amendment of the U.S. Constitution, the Court held that states may limit 
individual liberty in the service of well-established public health interventions. For over 100 years, this seminal opinion has served as the constitutional foundation for state actions limiting liberty in the name of public health.

Additionally, on May 28, 2021, the U.S. Equal Employment Opportunity Commission (EEOC) provided an updated guidance for COVID-19 vaccination (14). In this guidance, EEOC provided four key updates which included the following (adopted from the EEOC guidance):

a) Federal EEO laws do not prevent an employer from requiring all employees physically entering the workplace to be vaccinated for COVID-19, so long as employers comply with the reasonable accommodation provisions of the American with Disabilities Act and Title VII of the Civil Rights Act of 1964 and other EEO considerations

b) Federal EEO laws do not prevent or limit employers from offering incentives to employees to voluntarily provide documentation or other confirmation of vaccination obtained from a third party (not the employer) in the community, such as a pharmacy, personal health care provider, or public clinic

c) Employers that are administering vaccines to their employees may offer incentives for employees to be vaccinated, as long as the incentives are not coercive

d) Employers may provide employees and their family members with information to educate them about COVID-19 vaccines and raise awareness about the benefits of vaccination

It is predictable that to ensure patient safety, conversations to mandate COVID-19 vaccinations for workers are ongoing in many healthcare facilities across the U.S. A recent CNN report also implied that using rationale similar to that adopted by the Houston Methodist Hospital, two other major healthcare organizations in Houston, Texas are seriously considering implementing this mandate (15). Physicians, policymakers, and public health officials must engage in robust discussions related to legal and ethical issues encompassing mandated COVID-19 vaccination of healthcare employees. These intrepid actions are vital to protect the public and the patients from emerging and reemerging infectious diseases and other similar threats. In this informed decision-making process, it will be instructive to revisit lessons learned from current and previous pandemics and to use them as a guide to design and implement an effective, scalable and a sustainable model that is in the best interest of the public and the patients.

\section{References}

1. Medley, A. Houston Methodist Hospital makes COVID-19 vaccination mandatory for all employees. April 1, 2021. https://www.chron.com/coronavirus/article/HoustonMethodist-COVID-19-mandatory-vaccine-16070061.php

2. Pfizer-BioNTech COVID-19 Vaccine Emergency Use Authorization - Letter of Authorization. https://www.fda.gov/media/144412/download

3. Harkins, D. 117 staffers sue over Houston hospital's vaccine mandate, saying they don't want to be 'guinea pigs'. May 29, 2021. https://news.yahoo.com/117-staffers-sue-over-houston210313560.html

4. Trials of War Criminals before the Nuremberg Military Tribunals under Control Council Law No. 10", Vol. 2, pp. 181182. Washington, D.C.: U.S. Government Printing Office, 1949. https://archive.org/details/TrialsOfWarCriminalsBeforeTheNur embergMilitaryTribunalsUnderControlCouncil/Trials $\% 20$ of $\%$ 20 war $\% 20$ criminals $\% 20$ before $\% 20$ the $\% 20$ Nuremberg $\% 20$ Mil itary $\% 20$ Tribunals $\% 20$ under $\% 20$ Control $\% 20$ Council $\% 201$ law $\% 20$ no. $\% 2010 . \% 20$ -

$\% 20$ Nuremberg\%2C\%20October\%201946-

\%20April\%2C\%201949\%20Volume\%2010/page/n3/mode/2up

5. Polack, F.P., Thomas, S.J., Kitchin, N., et al., for the C4591001 Clinical Trial Group Safety and Efficacy of the BNT162b2 mRNA Covid-19 Vaccine. December 31, 2020. N Engl J Med 2020; 383:2603-2615. DOI: 10.1056/NEJMoa2034577

6. Baden, L. R., El Sahly, H.M., Essink, B., et al. Efficacy and Safety of the mRNA-1273 SARS-CoV-2 Vaccine. N Engl J Med. 2021 Feb 4;384(5):403-416. doi: 10.1056/NEJMoa2035389. Epub 2020 Dec 30.

7. Shimabukuro, T.T., Kim, S.Y., Myers, T.R., et al., for the CDC v-safe COVID-19 Pregnancy Registry Team.Preliminary Findings of mRNA Covid-19 Vaccine Safety in Pregnant Persons. April 21, 2021. N Engl J Med 2021: 1-10. DOI: 10.1056/NEJMoa2104983

8. Frenck, Jr, R.W., Klein, N.P., Kitchin, N., et.al., for the C4591001 Clinical Trial Group, Safety, Immunogenicity, and Efficacy of the BNT162b2 Covid-19 Vaccine in Adolescents. May 27, 2021. N Engl J Med 2021: 1-10. DOI: 10.1056/NEJMoa2107456

9. Centers for Disease Control \& Prevention COVID-19 Data Tracker. June 07, 2021. https://covid.cdc.gov/covid-datatracker/\#vaccinations 
10. Texas Health \& Human Services COVID-19 Vaccination Dashboard. June 03, 2021. https://tabexternal.dshs.texas.gov/t/THD/views/COVID19VaccineinTexasDashboard/Summary?:origin=card_share_li nk\&:embed $=\mathrm{y} \&:$ isGuestRedirectFromVizportal $=\mathrm{y}$

11. Edwards, E. Pfizer, BioNTech ask FDA for full approval of COVID-19 vaccine. May 07, 2021. https://www.nbcnews.com/health/health-news/pfizer-asks-fdafull-approval-its-covid-19-vaccine-n1266569

12. Lovelace, B., Jr. Moderna applies for full FDA approval of its COVID-19 vaccine. June 01, 2021 https://www.nbcnews.com/health/health-news/pfizer-asks-fdafull-approval-its-covid-19-vaccine-n1266569

13. Jacobson v. Massachusetts, 197 U.S. 11 https://supreme.justia.com/cases/federal/us/197/11/

14. EEOC Issues Updated COVID-19 Technical Assistance. https://www.eeoc.gov/newsroom/eeoc-issues-updated-covid19-technical-assistance

15. Andrew, S. A Texas hospital system will require employees to get the Covid-19 vaccine and could fire them if they don't comply. CNN: Updated 3:44 PM ET, Mon April 26, 2021 https://www.cnn.com/2021/04/26/us/houston-methodist-covidvaccine-mandate-trnd/index.html, et.al. Recent combined hormonal contraceptives (CHCs) and the risk of thromboembolism and other cardiovascular events in new users. Contraception. 2013 Jan;87(1):93-100. doi: 10.1016/j.contraception.2012.09.015. Epub 2012 Oct 19. PMID: 23083525.

9. Cheng Y-J, Liu Z-H, Yao F-J, Zeng W-T, Zheng D-D, Dong YG, et al. (2013) Current and Former Smoking and Risk for Venous Thromboembolism: A Systematic Review and MetaAnalysis. PLoS Med 10(9): e1001515 https://doi.org/10.1371/journal.pmed.1001515

\section{Sohail Rao, MD, MA, DPhil}

Executive Vice President, DHR Health, 5501 S. McColl Road, Edinburg, Texas

President \& Chief Executive Officer, DHR Health Institute for Research \& Development, 5323 S. McColl Road, Edinburg, Texas

Corresponding author email: s.rao@dhr-rgv.com

Disclosures: None

ORCID: Sohail Rao: https://orcid.org/0000-0001-50279992

Manish Singh, MD, FACS

Chief Executive Officer, DHR Health, 5501 S. McColl

Road, Edinburg, Texas

Disclosures: None
ORCID: Manish Singh: https://orcid.org/0000-00034146-3282

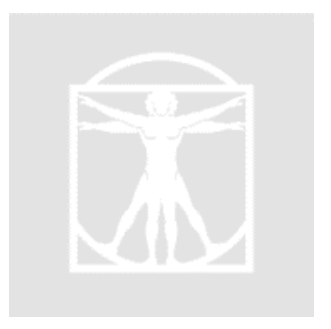

